\title{
On The Diachronic Analysis of Old English Metre
}

\author{
Professor Inna Matyushina \\ The Russian State University for the Humanities, Moscow, Russian Federation; \\ The University of Exeter \\ Great Britain
}

\begin{abstract}
The article is devoted to the diachronic analysis of Old English metre, based on the study of changes in the metrical structure of lines, modification of laws governing the placement of a caesura and the sound structure of alliteration, as well as transformations of the phonetic organisation of verse (the loss of certain types of sound devices, the appearance and spreading of others). As is shown in the article, the most important criteria for the diachronic analysis of Old English metre appear to be deviations from the canons governing the quantitative structure of alliteration (alliteration including palatal $\left[g^{\prime}\right]$ and velar [ $\left.\mathrm{g}\right]$; alliteration of voiceless consonants [hl-, $h n-, h r-, h w-] ;$ alliteration of consonant clusters [st, sp-, sl-, sn-, sw-]) as well as the use of double alliteration, studied with special reference to skaldic runhent. The main focus of the article is on the study of the sound organisation of half- and long lines. In nearly a third of the extant lines of Old English poetry, alliteration is enriched by additional sound devices, whose structure and function appear to be crucial for the diachronic study of Old English metre. In discussion of these in Old English verse not only full repetitions of vowels and consonants of root morphemes are considered, but also consonances, as these were canonised in other Germanic poetic traditions (i.e. Old Norse), preserving the skaldic system of internal rhyme (skothendingar - consonances used in odd lines, and aðalhendingar - full rhymes used in even lines). The distribution of full rhymes and consonances involving root morphemes is analysed in opposition to the sound repetitions of inflectional and suffixational morphemes. Inflectional rhymes resulting from rhythmic-syntactic parallelisms are taken into account, if they occur in isosyllabic units constituting rhythmic groups and in the same function as the rhymes of root morphemes. The function of consonances and full rhymes is studied not only in the units of poetic speech, such as compound words, lexical repetitions, repetitions of genetically related words and formulas, but also in the metrical units of verse. The change in the distribution of different types of full rhymes and consonances within half-lines and long lines can be accounted for by the changes taking place in the metrical organisation of alliterative verse.
\end{abstract}

Keywords: Old English poetry, verse, formula, metre, alliteration, rhyme, line.

Anglo-Saxon metre is usually analysed from a synchronic rather than a diachronic point of view, because of the difficulty of revealing 'undoubted facts of linguistic development' (Klaeber 1950: cix). The main reason for this is that Old English metre is highly conservative and not subjected to changes which are easily traceable. Scholars have often mentioned that the metre of Beowulf is hardly any different from the metre of the earliest Northumbrian poems or of the poems of The Anglo-Saxon Chronicle (Bliss 1967: 98-100). As dating presents an insoluble problem for the majority of Old English poems (with the exception of a few poems dated by external evidence, Fulk 1992: 368-369), the only method that can be applied in studying the evolution of metre is that of internal reconstruction which entails attempting to draw diachronic conclusions from a synchronic analysis of material (Kuryłowicz 1975: 40).

The development of Old English verse was influenced by a number of quantitative phonological changes, such as the appearance of epenthetic vowels, lengthening of vowels as a result of the loss of $[\mathrm{h}]$, shortenings due to the loss of intervocalic $[\mathrm{h}],[\mathrm{j}],[\mathrm{w}]$, the syncope and apocope of unstressed vowels (Amos 1980, Fulk 1992). Although these changes were reflected in the lengthening and shortening of the main units of alliterative verse, the presence of analogical forms used in typologically late poems makes them less reliable for the diachronic analysis of the verse than the study of its metrical and sound organisation. 


\section{Tendencies in metrical evolution}

The study of the evolution of Old English metre can be based on the analysis of changes in the metrical structure of lines, the modification of laws governing the placement of the caesura and the sound structure of alliteration, as well as the transformations of the phonetic organisation of verse (the loss of certain types of sound devices, the appearance and spread of others).

The main laws governing Old English metre can be summarised as follows: 1. Each half-line must contain no less than four syllables. 2. Each half-line must have two stresses (lifts). 3. At least one of the stressed syllables in a half-line must be included in the alliteration. 4. In even half-lines alliteration always falls on the first stressed syllable but never on the second.

Commonly used types of metrical filling in half-lines of alliterative verse were singled out by Eduard Sievers on the basis of detailed quantitative analysis (Sievers 1893). Most frequent in alliterative verse are half-lines with descending accentual alternation (resembling trochaic) of two stressed syllables (lifts) and two (or more) unstressed syllables (dips): e.g. gomban gyldan ${ }^{\mathrm{i}}$ Beow. 11: / X / X (type A according to Sievers). A little less frequent are the half lines with ascending alternation (resembling iambic) of stressed and unstressed syllables (e.g. on flodes æht Beow. 42): X / X / (type B according to Sievers). More rare are half-lines with the two stressed syllables placed in the middle next to each other (e.g. in geardagum Beow. 1): X / / X (type C according to Sievers). The least frequent are the two types with secondary stresses: with the initial combination of stresses (in two variants depending on the position of the secondary stress: e.g. heah Healfdene Beow. 57 or Fyrst forp gewat Beow. 210); / / X or / / X \, type D according to Sievers); and with the 'ring' arrangement of stressed syllables (also in two variants, e.g. lofdædum sceal Beow. 24 or medostigge mæt Beow. 924): / \X/ or / X \/, type E according to Sievers).

\section{a) Hypermetric lines}

Comparatively rarely in alliterative verse, lines can be found which do not conform to the system described above, as they contain a greater number of stressed (and unstressed) syllables than the lines of the five types singled out by Sievers. Hypermetric lines (Dehnverse) usually contain three stresses (instead of two), e.g. the first half-line in: æt fotum sæt frean Scyldinga // gehwylc hiora his ferhpe treowde Beow. 1166, in which stresses fall on the words: 'fotum', 'frean', 'Scyldinga' (the metrical scheme of this line represents the hypermetric variant of Sievers' $\mathrm{C}$ type with the stresses put in the middle of the first half-line: X / X / / X). The second half-line also contains three stresses (in the words: gehwylc, ferhpe, treowde) and resembles type A with the unstressed anacrusis: X / X / X / X. In Beowulf hypermetric lines occur rarely (11 long lines of 3182) and always in clusters (either of six lines: 1163-1168, or of three: 1705-1707, or of two: 2995-2996). In the extant corpus of Old English poetry there are more than 900 hypermetric half-lines spread across various poems (Pope 1982:100-104).

The function of hypermetric lines has been the subject of much scholarly debate. It has been suggested that such lines are used for the sake of emphasis (Sievers 1893: 216 \$185) and to slow down the poetic discourse (Pope 1966:120-124). Apart from the main functions of emphasis and slowing the tempo for the sake of artistic effect (Timmer 1951:226-230), secondary functions of hypermetric lines have been singled out, such as to introduce or to conclude a new compositional unit, to start or to end a poem (Timmer 1951:226-230). It was established that hypermetric lines most frequently occur in didactic and gnomic poetry (Timmer 1951:226-230), especially in the Cotton and Exeter gnomic poems (Rearhard 1984). On the contrary, in narrative poems concentrated on actions, hypermetric lines are avoided, which can be attributed to their main function of retardation in the narrative.

The function of slowing down the narrative tempo can be accounted for by the peculiarities of the linguistic filling of hypermetric lines. They frequently include prosodically heavy linguistic material, such as compound words and formulas: e.g. Sæton suhtergefæderan; / pa gyt wæs hiera sib ætgædere // æghwylc oðrum trywe. / Swylce pær Unferp pyle... (Beow. 1164-1165). A compound word 'suhtergefæderan', 'uncle and nephew', which has the prosodic structure / X / X, would have been by itself sufficient to fill a half-line, but it is accompanied by the alliterating verb, and consequently the half-line becomes hypermetric (type A / X / X / X ). The same metrical type (/ X / X / X) occurs in the next half-line, containing the formula 'æghwylc oðrum' (cf. gehwæper oðrum Beow. 814). Hypermetric lines with formulas and compound words usually occupy odd half-lines and always include double alliteration. 
An important peculiarity of the hypermetric lines quoted above consists in the use of sound repetitions additional to the canonical device of alliteration: the first line contains sound-repetitions of the final stressed syllables (similar to end-rhymes, see Part II below), suhtergefæderan - ætgæedere, whereas in the second line sound devices involve initial stressed syllables (similar to anaphoric rhymes, see Part II below), æghwylc - swylce. It can be suggested that alliteration by itself is not enough to organise a prosodically overburdened half-line, so hypermetric lines require an additional sound device to assist the alliteration.

Scholars have tried to employ the presence or absence of hypermetric lines (i.e. half-lines containing more than two stresses) as a criterion for dating Old English poems. Some believed that in early poems (especially those traditionally ascribed to Cynewulf) more hypermetric lines are used than in later poetry (Trautmann 1898:120). This hypothesis can hardly be proved as in a few datable early poems (Coedmon's Hymn, Bede's Death-song, The Leiden Riddle) hypermetric lines do not occur at all, and only one hypermetric line is used in A Proverb from Winfrid's Time (Oft daedlata 1a), dated $8^{\text {th }}$ century (Bredeshoft 2009:24); whereas in the late Battle of Maldon four hypermetric lines are found (54b, 61a, 91b, 98a) (Amos 1980: 97).

A contrasting suggestion has been that in archaic poetry hypermetric lines occur more rarely than in typologically late poems, making it possible to regard them as a result of the natural evolution of Old English metre (Lehmann 1956: 99). However hypermetric lines occur, though infrequently, in almost all poems, which is why their presence or absence can hardly be viewed as a reliable criterion in the analysis of the evolution of Old English metre.

\section{b) The law of metrical resolution}

In Old English alliterative verse the stress usually falls on the long syllable, but it can also fall on the short syllable, if it is followed by an unstressed syllable (also usually short). The metrical equivalence of two short syllables to one long syllable is called metrical resolution (in Sievers' terminology 'Auflösung'). Stress can also fall on a short syllable if it is preceded by a long syllable. In metre, as in grammar, the word 'scipu' is equivalent to the word 'hūs' in the nominative and accusative plural, but the same word in the genitive plural 'scipa' is equivalent to 'hūsa' (Bliss 1967:31). In other words, a short syllable followed by another short syllable is treated metrically as one long syllable (e.g., hire selfre sunu Beow. $1115 a-\mathrm{X} / \mathrm{X} /$ ), thus the resolution takes place; on the contrary, a short syllable followed by a long syllable is treated as a long syllable with the same long ending, if it occurs after a long syllable (e.g., scearp scyldwiga Beow. $288 a-/ / \mathrm{X}$ ), thus the resolution does not take place. The difference in the metrical treatment of short and long vocalic endings is accounted for not only by their morphological characteristics (short endings were lost after long stems, whereas long endings were preserved) but also by their phonological past (short endings go back to -i and -u, whereas long ones go back to -a and -æ, Bliss 1967: 119-120).

In the succession of syllables with the metrical scheme / $\backslash \mathrm{X} / \mathrm{X}$, where the second syllable is short, metrical resolution is almost always used, which makes it possible to describe it with the help of the scheme / $\backslash / \mathrm{X}$ (cf. Bliss 1967: 27-28: examples with a-stem neuter nouns: bengeato burston Beow. 1121a, brimclifu blican Beow. $222 a$; with wa-stem neuter nouns: sweordbealu sliðen Beow. 1147a, morðbeala mare Beow. 136a, guðsearo gumena Beow. 328a, fyrdsearo fuslic Beow. 2618a; with ō-stem feminine nouns: nydwracu nipgrim Beow. 193a, modceare micle Beow. 1778a; with i-stem masculine nouns: freowine folca Beow. 430a, winsele westne Beow. 2456a, mundgripe mægenes Beow. 1534a, laðbite lices Beow. 1122a; with u-stem masculine nouns: gomenwudu greted Beow. 1065a, sundwudu sohte Beow. 208a). In all examples resolution takes place when a short syllable is followed by a short vocalic ending.

On the contrary, in the succession of syllables / $\backslash \mathrm{X}$, in which the third syllable is short, metrical resolution is impossible, as otherwise this succession would have become an incomplete line / /, in which one syllable would have been missing. Thus resolution is avoided by a-stem masculine nouns: oflet lifdagas Beow. 1622a, n-stem masculine nouns: bat banlocan Beow. 742a, n-stem feminine nouns: eft eardlufan Beow. 692a, geong goldhroden Beow. 2025a, and various parts of speech ending in consonants: leof leodcyning Beow. 54a, geweold wigsigor Beow. 1554a, secg synbysig Beow. $2226 a$ (Bliss 1967: 29-30). In all the quoted examples a short syllable is followed by a syllable with a consonantal ending and the resolution does not take place. It was suggested that the short syllable was endowed with a secondary stress only in those cases when it was followed by a short vocalic ending (Bliss 1967:27-29), i.e. when it was equated with a long syllable. It is considered that almost all examples without resolution should have consonantal or long vocalic ending (Bliss 1967: 29-30). 
On the basis of Beowulf this hypothesis can hardly be always confirmed: 4 of 20 lines with resolution contain long or consonantal endings; but 51 of 133 lines without resolution contain short vocalic endings. In other poems, e.g. in The Battle of Maldon, deviations from the rule of metrical resolution are even more numerous (Bliss 1967: 103). In Old English poetry metrical resolution can occur in short syllables with both short and long endings, even if they do not follow the long syllable. The rule of metrical resolution in Old English verse is not observed consistently, therefore the analysis of metrical conditions in which two short syllables are resolved has to be regarded as an unreliable method of tracing the evolution of Old English metre.

\section{c) The position of the caesura}

The position of the caesura, coinciding or not coinciding with the syntactical border in the middle or at the end of the line, undergoes a significant change in the course of the Old English period. Old English metre is thought to have developed from an earlier kind of verse in which the caesura occurs at the end of the line to a later type in which the caesura is used in the middle of the line (Heusler 1957: 34-36, Malone 1943:201-204; Malone 1967:2628). Depending on the position of the caesura, four stages (or 'styles') in the evolution of Old English verse can be distinguished.

1. The earliest Anglo-Saxon 'style' (or 'the end-stopped style' of 'the oldest linear verse', Malone 1948: 26) can be recognised by lines which end in a syntactical pause: each sentence occupies one or two long lines (e.g. The Leiden Riddle or the lists of names in Widsið: Ætla weold Hunum, / Eormanric Gotum, // Becca Baningum, / Burgendum Gifica // Casere weold Creacum / ond Cælic Finnum, // Hagena Holmrygum / ond Heoden Glommum 18-21). Other examples of the coincidence of metrical and syntactical units occur in some formulaic lines in heroic poetry: Wulfgar mapelode / to his winedrihtne Beow. 360; Wiglaf mapelode, / Wighstsanes sunu Beow. 3076; Hroðgar mapelode, / helm Scyldinga Beow. 456, cf. also the consolatory formula in Deor: Pæs ofereode, / pisses swa mæg. The caesura is also placed at the end of the line in some formulaic gnomic verses (licgende beam / læsest groweð Maxims I 158).

2. The early 'run-on style' (Malone 1948: 26-28) with the caesura in the middle of the line can be exemplified by short groups of lines (usually not more than three or four), as in the remaining part of Widsið: Widsið maðolade, / wordhord onleac, // se pe monna mæst / mægpa ofer eorpan, // folca geondferde; / oft he on flette gepah // mynelicne mappum (1-4). In these lines two sentences could have formed two lines of the archaic type: Widsið maðolade, / wordhord onleac, $<\ldots>$ oft he on flette gepah // mynelicne mappum; but they are spread through four lines because of the introduction of the attributive clause: se pe monna mæst / mægpa ofer eorpan, // folca geondferde. Thus lines in which the syntactic division coincides with the metrical division (as in the first here) are combined with lines in which the caesura falls between two half-lines, i.e. in the middle of the long line (as in the second, third and fourth lines). In the first three lines the transition to the new line is achieved through a syntactic pause, as in the archaic type of line, but in the last line (oft he on flette gepah // mynelicne mappum) the transition takes place without a syntactical pause and therefore anticipates a new type of line organisation, characteristic of 'the classical style'.

3. Most frequent in Old English poetry is 'the classical run-on style' (Malone 1948: 26-28) with the caesura in the middle of the line. In the classical style sentences usually end at the boundary between half-lines and are hardly ever completed within the long line as such. Groups of lines are frequently organised into extensive units (consisting of any number of parts, sometimes more than 9 lines): Leoht eastan com, // beorht beacen Godes, / brimu swapredon, // pat ic sænæssas / geseon mihte, // windige weallas (Beow. 569-572). Such syntactical composition creates ideal conditions for the extensive use of epic variation, kennings, periphrastic constructions, poetic synonyms.

4. In the late 'run-on style' (Malone 1948: 26-28) with the caesura in the middle of the long line, no groups of poetic units shorter than the whole poem can be found (e.g. Judith, in which the metrical and the syntactical divisions coincide only in 11 lines of 350). The metrical division is so much stronger than the syntactical connections that attributes can sometimes be separated from the word they modify (cf. eodon ða stercedferhðe, // hæleð heora hearran cyðan 55-56; Nahte ic pinre næfre // miltse pon maran pearfe 91-92) or infinitives can be separated from the finite form of the verb (Ne wolde pæt wuldres dema // geðafian, prymmes hyrde 59-60). In all examples, parts of word-combinations are separated from each other and put into different long lines. Although the four stages or 'styles' based on the positioning of the caesura are not universally applicable to all Old English poems (Amos 1980: 98, Pope 1966:99), as their use is frequently restricted to isolated poems or even fragments of poems (e.g. lists of names in Widsið), 
Nevertheless analysis of the syntactical and the metrical division of poetic units and of the positioning of the caesura has to be taken into account as one of the tendencies in the evolution of Old English metre.

\section{d) Alliteration}

As mentioned above, the canons of alliterative verse require the use of alliteration on one of the stressed syllables in a half-line. In even half-lines it is always placed on the first lift but never on the second; in odd half-lines, however, it can be put on both stressed syllables and is then called 'double': e.g. Swa fela fyrena / feond mancynnes (Beow. 164).

1. In some Old English poems double alliteration occurs in more than half of the lines (1590 lines in Beowulf, 175 in Judith, 900 in Andreas, 94 in The Dream of the Rood); in other poems it is used in less than half of the lines (e.g. 47\% in Genesis B, 48\% in Elene and in Juliana, 47\% in The Battle of Brunanburh, 44\% in The Battle of Maldon, 20\% in The Paris Psalter) (Foster 1892:17-21). In The Rhyming Poem double alliteration occurs in 97\% lines, but this can be accounted for by the influence of skaldic metre runhent (Gurevich, Matyushina 2000: 7780). Although it is hard to find reliable proofs in favour of the hypothesis that double alliteration is typical of earlier poems and becomes less frequent with time (Foster 1892:17-21), the positioning of alliterating syllables remains an important factor in the evolution of Old English metre.

2. The study of the qualitative structure of alliterating syllables can also be used in the analysis of the development of Old English versification. It has been suggested that the palatal consonant [g'], which developed in the pre-literary period before all stressed vowels, as well as before the unstressed [i] and [j], and the velar consonant [g] were separate phonemes in Old English (Smirnitsky 1998). However, in some Old English poems (Beowulf, Judith, Genesis B, The Paris Psalter, The Metres of Boethius) palatal [g'] and velar [g] alliterate with each other: cf. in Judith alliteration on: girwan - gumena 9, goldwine - gumena - gytesalum 22, ongeaton grame 238, goldgifan - gæstes - gesne 279 (Timmer 1952:8-9). The palatal fricative consonant [j] in the name of the heroine alliterates four times with the velar consonant [g] (Iudith - gleaw 13, Iudith - guðe - god 123, Iudith galmoda 256, Iudithe - gleawe 334) and five times with palatal [g'] (gysterne - Iudithðe 40, Iudith - gingran gegnum 132, geomormodum - Iudith 144, ongeaton - Iudith 168, ageafon - gearoponcolre - Iudith 342) (Timmer 1952:8-9). But in the same poem alliteration on palatal consonants with velar consonants occurs with virtually the same frequency (cf. palatal alliteration: gifena - ginnan - gearwe 2, gesne - gæst 112, ginnan - togeanes 149; and velar alliteration: agotene - goda - gumena 32, grame - guðfrecan - garas 224, gargewinnes - greot 306, guðsceorp - gumena - golde 329, glædmode - gegan 140, gleawhydig - gumena 148, gleawe - golde 171, godes - gumena 186, guðfanum - gegan 219, gristbitian - gode 271, gargewinnes - greot 307) (Timmer 1952:8-9).

On the contrary, in typologically late poems (e.g. The Anglo-Saxon Chronicle poems, The Battle of Maldon, Menologium), as has been shown by a number of scholars (Campbell 1938: 33, Stanley 1975: 326), palatal consonants usually alliterate with palatal (cf. gearo and geornful, / gylpwordum spræc The Battle of Maldon 274, Pa hit pæt ongeaton / and georne gesawon The Battle of Maldon 84) and velar consonants alliterate with velar (grame garberend, / and god bædon 262; cf. 13, 32, 35, 46, 61, 94, 109, 138, 170, 176, 187, 237, 285, 287b, 315). In the 325 lines of The Battle of Maldon there are only three cases of alliteration of palatal with velar consonants: hwænne hi togædere / garas beron 67; Pær ongean gramum / gearowe stodon 100; Him se gysel ongan / geornlice fylstan $265^{\mathrm{ii}}$. In The Battle of Brunanburh velar also usually alliterates with velar (glad - grundas - godes 15 , garmittinge - gumena 50, grædigne - guðhafoc - græge 64), but the alliteration on velar and palatal is sometimes permitted (e.g. garum ageted / guma norðerna 18, giungne at guðe; / gelpan ne porfte 44). In The Rhyming Poem there is only one case of alliteration between palatal and velar (gold - gearwade - gim 36), two cases of alliteration on the palatal (giestas - gengdon - gerscype 11, gefest - gear - gellende 25), and five cases of alliteration on the velar consonants (glæd - gliwum - glenged 3, galdorwordum - gol - gomen 24, greteð ungrynde - grorn 49, gromtorn - græfep - græft 66, grofe - græf - grimme 71). Thus it can be suggested that poems with the prevailing alliteration on palatal with velar consonants can be regarded as typologically earlier than those in which velar alliterates with velar and palatal with palatal (cf. Amos 1980:102, Fulk 258).

3. Another type relevant for the diachronic study of Old English metre is alliteration on the voiceless consonants [hl-, hn-, hr-, hw-]. It has been posited that the graphemes $\langle$ hl- $\rangle,\langle\mathrm{hn}-\rangle,\langle\mathrm{hr}-\rangle,\langle\mathrm{hw}-\rangle$ denote consonants which remained voiceless after the disappearance of initial aspiration $[\chi]$ in the pre-literary period (Campbell 1959, $\S 461$; Sievers, Brunner 1951, §217, Luick 1964, §704). 
In Old English poetry a voiceless consonant alliterates both with an identical voiceless consonant and with the simple [h-]: in Beowulf [hl-, hn-, hr-, hw-] alliterate with [h-] in 61, 371, 456, 611, 952, 1114, 1236, 1490, 1929 , 3020, 3034, 3124, 3136, 3142, 3148, 3157, 3179 (Amos 1980: 94). This alliteration is also used in typologically later poems: in The Battle of Maldon (2, 14, 74, 112, 251, 318), The Battle of Brunanburh (39, 47) and in the poems of The Anglo-Saxon Chronicle (The Redemption of Five Boroughs 4, The Death of Edgar 35) (Amos 1980: 95). In Judith voiceless consonants also alliterate with the simple consonant [h-] (hl-/h- 259 and hr-/h 94, 289), as well as with each other (hl- 23, 205, hr- 282, hw-214), but a completely new type of alliteration appears here: [hw-] begins to alliterate with [w-] (weras werigferhðe / hwearfum pringan 249), and [hr-] alliterates with [r-] (reocende hræw. / Rum wæs to nimanne 313) (Foster 1892:26). The new type of alliteration appearing in Judith [hw-/w-, hr-/r-] could testify to the beginning of the process of voicing previously voiceless sonorants (Amos 1980: 94).

Additional evidence that the process of voicing was starting is the appearance of alliteration of the voiceless consonant [hw-] with the voiced [w-], and voiceless [hr-] with voiced [r-] in other poems. Thus in The Battle of Maldon [hr-] most likely alliterates with [r-] (reaf and hringas / and gerenod swurd 161) but in the same poem [hr-] definitely alliterates with [h-], followed by the vowel (purh ða hringlocan, / him æt heortan stod 145). Alliteration of voiceless [hw-] with voiced [w-] is probably present (together with the common alliteration of [hr-] with [hr-]) in one of the earliest datable Old English poems, the eighth-century Leiden Riddle: Wile mec mon hwæpre sepeah / wide ofer eorpan 11 (Amos 1980: 95). By the end of the Old English period voiceless consonants [hl-, hn-, hr-] become voiced due to assimilation with the following vowels, and starting from the $12^{\text {th }}$ century they are rendered as $\langle 1-, \mathrm{n}-, \mathrm{r}-\rangle$ in manuscripts (Luick 1964). It is thought that the process of voicing the voiceless sonorant hr- and its merging with the simple consonant [r-] had ended by the middle of the $11^{\text {th }}$ century, whereas voiceless [hn-, hl-, hw-] remained different from simple [n-, l-, w-] (Goossens 1969). Moreover the process of voicing did not take place simultaneously in different dialects: [hl-, hn-, hr-] developed into [n-, l-, r-] first in Northern dialects and then in others, whereas it was in the Southern dialects that the voiceless consonant [hw-] first developed into [w-] (Amos 1980: 94). Thus although the evidence of alliteration on voiceless sonorants can be regarded as a factor in the evolution of Old English metre, its reliability is complicated by dialectal variations.

4. In typologically early poems, groups of consonants [st-, sp-, sl-, sn-, sw-] alliterate only with themselves as if they form one unit but in later poems they can alliterate with the simple consonant [s-], e.g. in The Battle of Maldon [sn-], [st-] and [sw-] alliterate with the simple consonant [s-]: Me sendon to pe / sæmen snelle 29; Sibyrhtes broðor / and swiðe mænig oper 280; æfre embe stunde / he sealde sume wunde 271 (Foster 1892:23). In the last quoted example a precise rhyme of 'stunde : wunde' is used, perhaps, to compensate for the defect in the alliteration.

In Judith groups of consonants also usually alliterate with themselves (cf. [sn-]: 125, 199, [sw-]: 80, 106, 240, 322), however the group [sl-] alliterates not only with itself (247), but also with the simple consonant [s-], followed by a vowel $(88,89,124)$ (Foster 1892:23). An alliteration used in Judith of [sn-] with [st-] (Snuðe ða snoteran idese / eodon ða stercedferhðe 55) is similar to an alliteration in one of the very few datable Old English poems (The Redemption of Five Boroughs, included in The Anglo-Saxon Chronicle as the entry for 942), in which the toponyms Snotingaham и Stanford (7) are included in the alliteration.

As alliterations of groups of consonants with simple consonants followed by a vowel appear in typologically late poems, this deviation from the alliterative canon is relevant in the evolution of Old English metre. Thus the use of double alliteration as well as deviations from the canons governing the quantitative structure of alliteration (alliteration including palatal [g'] and velar [g], alliteration of voiceless consonants [hl-, hn-, hr-, hw-], alliteration of consonant clusters [st, sp-, sl-, sn-, sw-]), appear to be among the most important tendencies in the diachronic development of Old English metre.

\section{The function of sound repetitions in metrical evolution}

Although Friedrich Kluge published his lists of rhymes in Old English and Old Norse poems at the end of the $19^{\text {th }}$ century (Kluge 1884: 422-450), the sound organisation of alliterative verse did not receive scholarly attention and, as far as is known, was not employed in the diachronic study of Old English metre. Following Kluge, scholars usually agree in very general terms that the use of rhyme increased in late Old English. 
However, the few who wrote on the subject invariably reject the value of rhyme for diachronic metrical studies on different grounds, such as a conservative or innovative style in the creators of particular Old English poems or their individual metrical idiosyncrasies (Foster 1892: 28-33, Campbell 1938: 33, Pope 1966: 104, Amos 1980: 93).

Yet in nearly a third of the extant lines of Old English poetry, alliteration is enriched by additional sound devices, whose structure and function appear to be crucial for the development of Old English metre. These sound devices vary from full repetitions of the vowels and consonants of root morphemes in the stressed syllables (stunde : wunde, sceoldon : heoldon, wide : side, gleam : dream) to consonances of stressed syllables (hund : wond, ping : leng), which were canonised in other Germanic poetic traditions (i.e. Old Norse), preserving the skaldic system of internal rhyme (skothendingar - consonances used in odd lines, and aðalhendingar - full rhymes used in even lines). Secondary forms (skaldic rhymes) cast their reflection on forms which are typologically earlier (soundpatterns in the Poetic Edda) where full rhymes and consonances of the 'skaldic type' are highly significant, noticeable and perform their function, keeping one Eddic poem distinct from another (Matyushina 1994: 103138).

Methods elaborated on the basis of the study of skaldic and Eddic verse can be applied to singling out rhymes in Old English. As in skaldic skothendingar and Eddic consonances, the phonetic similarity in Old English rhyme is naturally dependent on consonants, which belong to the invariable element of the root morpheme, responsible for conveying the semantics of the stem. Assonances of stressed syllables are taken into account, only if they are used in two or more lines in succession and under similar metrical conditions, and if they occur side by side with other types of rhymes of root morphemes (as in the epilogue of Elene 11. 1242-1246, where assonances wæf : læs appear side by side with full rhymes such as fus : hus, nearwe : gearwe).

Sound devices additional to alliteration are indivisible from the accentual structure of the verse, i.e. their position is determined by the four stressed syllables of the alliterative long line. Embryonic forms of rhyme include any identical stressed root morphemes, even if they are followed by varying unstressed syllables (fæederan : ætgædere, healdanne : gewealdene), or if the final unstressed syllable is wholly or partially missing (sealde : anweldan, grunden : gemunde). On the contrary, even the most precise repetitions of sounds in unstressed syllables (earm ic wæs on eole pinum / pæt wurde eadig on minum), or the sound repetitions formed by an unstressed syllable with a stressed syllable (man : habban, stod : gewurðod, willan : can) are not viewed as rhymes in Old English verse, though they obviously play a part in the sound instrumentation of the line.

Full rhymes and consonances involving root morphemes have to be kept distinct from the sound repetitions of inflectional and suffixational morphemes. Inflectional rhymes resulting from rhythmic-syntactic parallelisms are taken into account, if they occur in isosyllabic units constituting rhythmic groups and in the same function as the rhymes of root morphemes (e.g. ne forstes fnæst / ne fyres blæst // ne hægles hryre / ne hrimes dryre // ne sunnan hætu / ne sincaldu Phoenix 15-17).

Suffixational repetitions of sounds usually occur at the end of neighbouring half-lines or long lines, so their position is more restricted than the place of the rhymes of root morphemes. If root morpheme rhymes are connected with the expression of lexical meaning, suffixational and inflected repetitions of sounds underline the grammatical meaning of the word. Therefore unlike root rhymes, which are always semantically charged, they do not have a specific semantic impact, so are closer to purely sound devices. The use of these sound repetitions is determined by the rhythmical-syntactical parallelism, and requires the verse to be so structured that half- lines end in words of identical syntactical function (cf. the rhythmical and syntactical parallelism of superlative epithets at the end of Beowulf : manna mildust / ond monpwærust // leodum liðost / ond lofgernost 3181-3182). Inflectional rhymes anticipate the canonisation of end rhymes and give a historical perspective on the development of rhyme in later poetry.

\section{a) Full rhyme born in lexical repetitions}

In Old English poetry, as well as in Eddic verse (Matyushina 1994:103-138), a particular word is frequently repeated in a different morphological form, which results in a very precise sound repetition of the stressed syllables of the root morphemes. Within one half-line the same word can be repeated in different grammatical forms, either with prepositions (27 examples, e.g. an æfter anum Beow. 2461a, wrað wið wraðum Elene 1182a) or without (37 examples, e.g. in dreama dream Christ 580a, ealra cyning cyning Juliana, 289a). In some cases lexical repetitions consist not of the same words, but of words which are etymologically related ( 24 examples, e.g. gyfeð gyfe Paris Psalter 83/12a, ceose mid gecorenum Paris Psalter 105/5a). 
In contrast to exact lexical repetition, creating the effect of full rhymes, the repetition of etymologically cognate words or the use of different grammatical forms of one and the same word provide the linguistic grounds for bringing into use consonance of root morphemes. The non-identity of vowels can, usually, be accounted for by ablaut, as in the case of a derivative and the word from which it has been derived (ceose : gecorenum). As mentioned above, sound proximity is based on consonants, because they form the constant part of the root, responsible for the expression of meaning, whereas vowels, varying according to ablaut or other mutations, only modify the grammatical or derivational structure of the word. The semantic weight of repetitions, containing both full consonances and identical initial sounds, determines their location in verse-units: they invariably coincide with the main accents in the line. Undoubtedly, the full consonance in the root morpheme of etymologically cognate words has not yet abstracted itself from language substance and has therefore not yet become a pure sound-device. Lexical repetitions are ancient features of folklore, originating in gnomic and didactic poetry, and are connected with belief in the magic powers of words (Meletinsky 1986: 15-31). However in Old Germanic poetry (e.g. in Eddic verse) lexical repetitions only retain faint echoes of a magical function, which is already ousted by their stylistic function. In Old English verse the main function of lexical repetitions consists in enhancing the meaning of a word and singling it out from the flow of the verse. Rhyme here, as in the case of compound words with rhyming components, helps to bring the whole word into prominence.

Repetitions of genetically related words are used to underline their common logical-semantic sphere. In etymological repetition, the phonetic resemblance may not be as great as in complete repetition of words, but it is not the sound likeness as such that is important but the semantic proximity of the related words. Thus logical parallelism prevails here over phonetic similarity.

Repetitions of words entail not only full rhyme of the root morphemes but also alliteration. Therefore according to the laws of alliterative verse prohibiting alliteration on the last stressed syllable in even half-lines, the use of lexical and etymological repetition is restricted to odd half- lines. Because lexical repetitions frequently contain unstressed syllables, including prepositions or pronouns, they are capable of fully organizing the structure of a half-line. As they contain alliteration enhanced by full rhyme, lexical repetitions occupying the positions of first and second stressed syllables in a long line provide valuable material for organising the structure of both types of line (long and half-line) of alliterative verse.

Should the need arise to use a lexical repetition in an even half-line, a variant with the word 'oðer' appears. The distribution of both variants can be shown with the help of the following example: fyrd sceal wið fyrde / feond wið oðrum (The Proverb from Winfrid's Time 52). Similar constructions with 'oðer' always occur in even halflines, e.g. in Beowulf (652b, 870b, 2484b, 2985b), Andreas (138b, 1165b), Elene (233b). The only exceptions to this rule are the formulas 'broðor oðrum' (Riddle 44, 12a), 'broðor oðerne' (Beow. 2441a), which occur in the odd half-line. However, in this case the formula does not contain a lexical repetition (i.e. a unit of the poetic language), but a purely sound device, the internal rhyme (see Part II below), similar to the internal rhyme which was canonised in skaldic poetry.

\section{b) Full rhyme resulting from repetitions of morphemes of compound words}

In Old English poetry full root rhyme enriched by alliteration can emerge in formulas whose components are partially identical. Repetitions of one of the morphemes of compound words provide the closest parallel to lexical repetitions. If the first morpheme is repeated, then alliteration inevitably accompanies rhyme (e.g. Godwine and Godwig Maldon 192a, Hroðwulf and Hroðgar Widsið 45a). If the second morpheme is repeated, then alliteration becomes optional (Oswold and Ealdwold Maldon 304a, Ordlaf and Guðlaf Finnsburg 16b, nioðoweard and ufeweard Phœenix 299a, rædhere and rondhere Widsið 123a). In spite of the difference of the first components, usually functioning as attributes, the meaning of such compound words is close to contextual synonymy (e.g. egeslic and gromlic - 'awful and fierce', Christ 918b, nioðoweard and ufeweard - 'lower and upper parts' Phœenix 299a, rædhere and rondhere - 'riders and shield-warriors' Widsið 123a), which is sometimes additionally underlined by an indigenous sign of kinship such as alliteration, as in the latter example. Thus, as a result of the repetition of a morpheme, the pairs of compound words constituting the formula appear to be connected by a deep sound-repetition enhancing their semantic and structural relation to each other. Logical parallelism in such formulas prevails over phonetic similarity.

In those (rarer) cases when only the first components of compound words in the formula are repeated (e.g. Godwine and Godwig, Maldon 192a, Hroðwulf and Hroðgar Widsið 45a), the interpretation of the semantics of the constituent parts is more difficult, because only proper names are used in such formulas. 
However here, as in the preceding type of formula, the sound similarity is only the result of the identity of lexemes. As can be seen from the examples given, repetition of morphemes is frequently used in lists of names (cf. skaldic pulur, i.e. lists of heiti in Old Norse poetic tradition) based on the model of binary formulas.

According to the model of binary formulas, lists of names are frequently organised around the same sound repetitions, full rhyme and consonance, often united with alliteration (e.g. Seccan and Beccan Widsið 115a). Apart from a mnemonic function, which is most important in such lists of names, sound repetitions here also organise words (in this case proper nouns) into compact, self-contained, distinguishable units of the total text. In formulas whose components are partially identical, rhyme has not yet detached itself from the texture of the language nor developed into a metrical device.

\section{c) Sound devices in formulas}

The use of formulas having both rhyme and alliteration is, according to the laws of alliterative verse, limited to odd half-lines. The main function of rhyme here is to deepen the sound repetition provided by alliteration and thus to build the main unit of alliterative verse, the half-line, more compactly (Matyushina 2011:31-53). The fairly small number of formulas containing rhyme and alliteration (eight instances of full rhyme, such as freond and feond Elene 954a; weceð and wreceð Daniel 576a, sar and swar Christ 1411a; as against twenty-eight instances of consonance such as brimes and beames Riddles 10/6a, lofigen and lufigen Azariah 100a, neode and nyde Christ 1068a) can be accounted for by the fact that rhyme and alliteration are of their nature conflicting devices. For the organisation of formulas as units of poetic language only one poetic device is normally chosen, either rhyme or alliteration. Because rhymed formulas occur in verse where the structural role is played by alliteration, the rhyme which organises them as units of poetic language, and the alliteration which organises the verse, coexist in different spheres: in language and in verse. In formulas which are both rhymed and alliterating, the contact between rhyme, pertaining to the units of poetic language, and alliteration, used in building the units of verse, is achieved on a linguistic rather than poetic basis.

In the majority of binary formulas in Old English, preference is given either to full rhyme (e.g. in Genesis: wide and side $10 b, 117 b, 118 b$, steapes and geapes $1942 b$, freed and nerede $1397 a$, gleam and dream $12 b$ ) or to consonance of the root morphemes (e.g. in The Metres of Boethius: east and west 10/5b, suð oððe norð 10/24b, wordum and dædum 16/23b, leohtre and berhtre $22 / 22 a$ ) or to sound repetition in the inflectional morphemes (e.g. heofonas and englas, Daniel 364a, winteres and sumeres, Phoenix 37a). The sound repetitions appearing in the components of formulas which either fully rhyme or consonate are less intimately connected with the lexical (or grammatical) meaning of their constituent parts than in lexical or etymological repetitions. However, in these cases the sound repetition is also used in grammatically homogenous words, related to each other according to a logical principle. The logical bases for uniting words in formulas, structurally underlining that the objects or notions they denote are related, are so transparent that binary formulas can be classified semantically. In works dedicated to the analysis of Old Germanic formulas, it is common to single out the following three main means of semantic organisation of the components of binary formulas: contrast, similarity and complementarity (e.g. Gurevich 1986: 32-55).

In all three kinds of formula, it is the internal semantic connection between the components of the formula that ensures its structural wholeness as a unit of poetic text, whereas the external, formal means of organisation, such as rhyme and alliteration, only add to the appearance of being isolated and standing out from the flow of verse. The semantic relations between the components of rhymed formulas seem to determine the frequency of their occurrence. Rhymed formulas, consisting of synonyms (hlynede and dynede Judith 23b, sægdan and cwædan Paris Psalter 82.3a), i.e. tautological formulas, occur very rarely. Leaving aside formulas whose components can be regarded as contextual synonyms (e.g. beorhte and leohte Elene 92a), only a few isolated examples of tautological formulas were found in Old English poems. Formulas consisting of antonyms, i.e. antithetic formulas, (e.g. freond and feond Elene 954a, englum and deoflum Christ 898b) occur more often (approximately 40 examples). Most frequently the components of rhyming and/or alliterating binary formulas complement each other (over 240 examples). In complementing binary formulas, tight structural organisation is not matched by a tightness of semantic connection, which on the contrary appears looser than in tautological or in antithetic formulas. Therefore it seems that a need arises for further formal devices to strengthen the connection between the components of a formula. These formal devices are alliteration and rhyme. 
In contrast to the examples given above, where the lexical connection of the components of the formulas served as a basis for the sound repetition, inflectional rhymes appear as a result of the grammatical identity of the constituents of the primary formula. In such cases, sound similarity is also secondary and follows necessarily from the juxtaposition of words which are related, that is, belong to one morphological class and share the same grammatical form.

Inflectional rhymes and root rhymes are both usually employed in symmetrical formulas ${ }^{\mathrm{iii}}$, i.e. those which include words of identical morphological class, grammatical form and prosodic structure, generally consisting of one syllable (e.g. dream and gleam Genesis 12b), two (e.g. wide and side Christ 394b, Dream of the Rood 76b, Genesis 10b, 117b, 118b, Guthlac 882a, Paris Psalter 56.13b etc.) or more (e.g. ferede and nerede Genesis 1397a), and sometimes containing alliteration alongside rhyme (e.g. freond and feond Elene 954a, weceð and wreceð Daniel 576a, sar and swar Christ 1422a).

Rhymed formulas reveal the unity of form and meaning characteristic of alliterative poetry. The semantic proximity here finds its organic manifestation in the formal proximity: not purely a phonetic but rather a phonomorphological likeness brought into prominence by the prosodic isomorphism of the constituent parts. In rhymed formulas any kind of sound likeness (alliteration, consonance, inflectional rhyme resulting from morphological-syntactic parallelism) is as important as semantic relation of the united words. This makes it possible to view rhymed formulas as units of poetic language, regularly reproduced in verse texts. Sound repetitions are used in rhymed formulas not to create metrical units but to achieve a more compact organisation of blocks of poetic speech. The indivisibility of sound structures and language structures is an intrinsic aspect of the alliterative technique, strictly controlling their distribution in verse.

Formulas without alliteration, i.e. containing rhyme only, tend to be used in even half-lines (of 286 examples of rhymed formulas, 223 are used in even lines). Only in even lines formulas like 'wordum and bordum' (Elene 24b), 'widdra and siddra' (Exodus 428 b), 'wædum and dædum' (Be monna wyrdum 90b) can be found. A formula which is spread very widely in Old English poetry, 'wide and side', occurs 14 times in even lines and only once in an odd line. Although formulas are units of poetic language, they function in the alliterative verse and participate in organising verse-units, i.e. half-lines. Rhymed formulas (as in the examples given above) include in the sound repetition the weakest (fourth) syllable in the alliterative long line, which was never involved into alliterative patterns. Thus the metrical hierarchy of stresses in the long line is violated. Moreover the consolidation of the half-line, the whole of which is filled with the rhymed formula, destroys the autonomy of the long line, weakening its prosodic rhythm and thus anticipates one of the directions of the evolution of Old English metre.

\section{d) Sound repetitions within half-lines}

Rhymes emerging in units of poetic language, such as lexical repetitions, rhymed formulas and compound words with rhyming components, serve as the basis for the appearance of a most archaic sound device, i.e. internal rhyme confined within the limits of a half-line. In contrast with the rhyme employed in the units of poetic language, internal rhyme is a sound device in the proper sense of the word, that is, it takes part in creating the units of verse. This device consists in the appearance of sporadic facultative rhyme side by side with the canonical alliteration, uniting metrically significant words in the line (e.g. purh sliðne nið Beow. 184a, feorhbealo feorran Beow. 156a, wean onwendan Beow. 191a). Alliteration here builds the accentual scheme of the half-line, whereas the rhyme merely enhances its structure.

Sometimes, though very rarely, internal rhymes begin to occupy the fourth (weakest) metrical position in the long line where it will establish itself in the course of time. But in typologically early poems, this kind of rhyme tends to be used in odd lines. For instance, in Elene 17 internal rhymes (e.g. fæste gelæston 1212a, abreotan on beorge 510a) occur in odd half-lines, and only 3 examples are found in even half-lines). In Beowulf forty internal rhymes (e.g. mæton merestræta 514a, lond Brondinga 521a, hearde heaðoscearde 2829a) of a total of fifty-three occur in odd lines. As can be seen in the quoted examples, the rhyme is merely added to alliteration, either involving the non-alliterating syllable into the repetition of sounds or expanding the sound-repetition assigned by alliteration.

In typologically later texts the positioning of internal rhymes changes. In The Battle of Maldon (325 lines) there occur six internal rhymes, five of which are situated in even lines, e.g. leofne fleogan $7 \mathrm{~b}$, feallan sceolon 54b, bord ord onfeng 110b, eorl to pam ceorle 132b. In the Battle of Brunanburh three internal rhymes can be found, all of which occur in even lines: lapum peodum $22 \mathrm{~b}$, nede gebeded $33 \mathrm{~b}$, wundun forgrunden $43 \mathrm{~b}$. 
In The Ruin all internal rhymes occur in even half-lines only: scorene bedrorene $4 \mathrm{~b}$, forweorone geleorone $7 \mathrm{~b}$, weal eal befeng $42 \mathrm{~b}$, hryne wong gecrong 334b. The main function of internal rhymes (together with rhyme in the units of poetic language, such as compound words with rhyming components, formulas and lexical repetitions) is to strengthen one of the two main units of alliterative verse, the half-line. Strengthening of the half-line undermines the autonomy of the long line, weakening its phrasal rhythm.

In typologically early poems (e.g. in Beowulf or in Elene) internal rhymes are frequent and tend to be used in odd half-lines; in typologically late poems internal rhymes occur more rarely and are usually restricted to even lines, involving the weakest position of the fourth lift and disrupting the hierarchy of metrical stresses in alliterative verse.

\section{e) Sound repetitions within long lines}

In Old English verse sound repetitions additional to alliteration can occur not only within half-lines but also in long lines. Anaphoric rhymes can be created if words with the same root morpheme (or genetically similar words) are placed at the beginning of odd and even half-lines (in the position of the first and the third lift), united into one long line: mon on mode / mondryhtne bær (Beow. 2281), hæle hildedeor / hæleða mongum (Beow. 3112). In these positions at the first and third lifts, words unrelated etymologically can be found: wið steall geworht / ic рæð wealles geat (Juliana 401). With the help of this sound-device, the most frequent in Old English poetry (354 examples), two very strongly stressed syllables, which usually alliterated, are united. The rhyme of the root morphemes here is fully subordinated to alliteration, facilitating the organisation of the rhythmically diverse material into the main poetic unit of alliterative verse, the long line.

Less frequent are rhymes on the borders of half lines (306 examples), which like anaphoric sound repetitions involve either etymologically cognate words (purh hreðra gehygð / hyges cunnian Beow. 2046, lað ond longsum / wæs hit lengra first Beow. 134) or words which are genetically unrelated (eafoð uncuðes / uðe is swiðor Beow. 960 , fyr on flode / ne pæs frod leofa Beow.136). The only difference between this type of sound repetition, which could be called 'border rhyme', and the anaphoric rhyme consists in that the former involves not the first lift of the line but the second and the third. In anaphoric and border rhymes the third lift, prosodically the strongest, always takes part in the sound repetition, whereas the first and the second are alternatives. In the 3182 lines of Beowulf anaphoric and border rhymes are used to unite 668 half-lines (including precise rhymes, assonances and consonances) and are distributed almost equally (353 cases of anaphora and 315 on the border of two half-lines). In the 1321 lines of Elene there are 228 lines containing repetitions of the first or second and the third lift (132 examples of anaphora, 96 of border). Thus in Beowulf and Elene one fifth of all the lines are united by anaphoric or border sound repetition. Repetition of sounds at the first and third lifts occurs slightly more frequently than at the second and the third, which precisely corresponds to the placement of alliteration: the first and third stressed syllables alliterate more frequently than the second and the third.

In typologically later poems the number of anaphoric and border sound repetitions decreases. In The Battle of Maldon (325 lines) there occur only 16 cases of anaphora and border sound devices, and in the poems of The Anglo-Saxon Chronicle only one. The decrease in the number of sound devices on the first, second and third lifts is conditioned by the weakening of the stress pattern of the long line and the levelling of the lifts in the typologically late poems. The second lift alliterates here as frequently as the first; moreover the third lift is not always included in the alliteration, as in one of The Anglo-Saxon Chronicle poems The Death of Alfred (syppan Dene common / and her frið namon 7; æt pam westende, / pam styple ful gehende 19). This is why it is hardly surprising that sound devices in typologically late poems move from the first three lifts to the weakest stressed position in the long line, the fourth lift.

Ring sound devices unite the fourth lift with the first: heardra hynðo / Heorot eardoda (Beow. 166), wong wisian / he ofer willan gong (Beow. 2409). In Old English poems this type of sound repetition occurs more rarely than anaphora and border rhyme (in Beowulf 17 examples; in Elene 8). Because of the small number of examples (a total of 60 in all the extant poetry) it is hard to trace their distribution between poems. The rarity of ring sound devices can be accounted for by their controversial function: on the one hand, they underline the autonomous character of the long line; on the other hand, they equate the prosodically strong first lift with the prosodically weakest fourth lift and thus share in the weakening of the accentual pattern of the long line. The need to strengthen the end of the line with the help of this kind of sound device is determined by the difference between the syntactical and the metrical organisation of lines in Old English verse. 
Anaphoric, border and ring sound devices strengthen the metrical organisation of alliterative verse. Based on the contradiction inherent in the structure of the long line, they are either added to alliteration (anaphora and border types) and thus deepen the sound device, or, by involving the non-alliterating syllables (ring type), they help alliteration to underline the metrical equivalence of all four lifts. By emphasising the autonomous nature of the long line, these sound devices strengthen the horizontal organisation of verse units typical of alliterative verse. This is why these sound devices did not develop in later poetry: they could only exist within the old system of alliterative verse.

\section{f) Sound repetitions at the end of half-lines and long lines}

Sound devices involving the last two lifts in neighbouring half-lines (second and fourth) are used in the typologically earliest poems. End rhymes occur already in the Hymn ascribed to Cædmon, the first English poet known to us by name: pa middan-geard / monn-cynnes weard (7). In other typologically early Christian poems (Daniel, Exodus, Genesis) end sound repetitions occur rarely, the combination of sounds found once is reproduced again and again: pa him wlite beorhte / uæstmas brohte (Genesis A 1561/943); ides wlitebeorht / on woruld brohte (Genesis A 1728 / 1112).

As can be seen from these examples, the main peculiarity of typologically early end-sound repetitions is that they find support in alliteration. In these and similar cases in addition to the main alliteration falling on the first and third lifts, root rhymes create their own alliterative pattern and extend it to the final lifts (second and fourth) in half-lines. Most cases of the rarely occurring crossed alliteration can be accounted for by the fact that imprecise end-sound repetition seeks support in the canonised sound-device, alliteration: leodon cyðeð / ponne lipan cymeð (Gnom. 106); fepre on lifte / feredon mid liste (Riddles 27, 4; 16 examples in the whole corpus). The term 'alliteration' applied to the repetitions of sounds in the last lifts of half-lines stresses their phonetic aspect, disregarding the semantic value of alliteration which was so important for the whole tradition of Germanic versification. In contrast to Germanic alliteration (as well as those repetitions of sounds which strengthened it), always marking the semantically most important words in the line, sound devices involving the end lifts in the half-lines, have a different nature and do not create semantically motivated sound connections between words.

The number of sound devices helping to correlate the weakest positions in the alliterative verse (second and fourth) increases in typologically late poems. In Beowulf there are six precise end-sound repetitions and seven imprecise, whereas in the famous epilogue to Elene fifteen end-sound devices are used. Side by side with precise rhymes (fus : hus, nearwe : gearwe) there appear assonances (wæf : læs) and consonances (reht : gepæht) (Elene 1242-1246). In other poems of the so-called Cynewulfian cycle (Juliana, Christ, The Fates of the Apostles) not only isolated lines but whole groups of verses correlated by end rhymes occur (Christ 590-597; 1643-1647).

In contrast to end-sound repetitions, any other types of sound device (anaphora, border, ring), which were mentioned as unrealised possibilities of the types of metrical composition, serve to unite half-lines. Placed on metrically strong lifts they help alliteration to maintain the horizontal principle of the organisation of long lines. On the contrary, end-sound devices, involving the weakest lifts and marking the boundary of the half-lines, serve not to unite them but rather establish a correlation between them, thus marking the structural relation of one sound-row to another. This kind of sound device can correlate not only the horizontally neighbouring half-lines, forming one long line (fylle gefægon / fægere gepægon Beow. 1014), but also those which are next to each other vertically, comprising parts of different long lines (forð gefremede. / Hwæpere him on ferhpe greow // breosthord blodreow; / nallas beagas geaf Beow. 1718-1719) thus anticipating in embryonic form of the organisation of a stanza.

In typologically early poems, sound devices correlating different long lines are relatively rare (in Beowulf only seven examples). In typologically early Christian poems they are also infrequent (in Daniel 2, in Genesis 6, in Exodus none). In these poems such sound repetitions are usually imprecise and motivated by morphological or syntactic parallelism: wæron mancynnes / metode dyrust // dugopa drymust / drihtne leofast (Daniel 36-37). In the lines quoted above, the final (fourth) lift of the first long line anticipates the alliteration of the second long line. Thus even this type of sound device, which is by definition free from any connection with alliteration, is indivisible from it in typologically early poems.

In comparison with end-sound devices which are rarely used to correlate long lines, other types of sound repetition were frequently employed in typologically early poems to unite long lines with each other. 
These sound devices were usually extended to the main lifts of the neighboring long lines: (a) the first lifts of the even and of the neighbouring odd half-lines: gold glitinian / grunde getenge, // wundor on wealle; / ond pæs wyrmes denn (Beow. 2758-2759; altogether 22 examples in Beowulf, 20 examples in Genesis, 9 examples in Exodus); (b) the third lift of one long line and the second lift of the neighbouring long line: weana ne wende / to widan feore // bote gebidan, / ponne blode fah (Beow. 933-934; altogether 16 examples in Beowulf, 17 examples in Genesis, 6 examples in Exodus); (c) the fourth lift of one long line and the first lift of the neighbouring long line: ic him pa maðmas, / pe he me sealde, // geald æt guðe, / swa me gifeðe wæs (Beow. 2490 - 2491; altogether 9 examples in Beowulf, 11 examples in Genesis, 3 examples in Exodus). The distribution of the sound devices in long lines is similar to the distribution of anaphoric, border and ring sound devices within long lines, which shows that only lifts were used as traditional positions of sound repetition in typologically early Old English poetry. The frequency of sound repetition, uniting neighbouring long lines, can be accounted for by the main peculiarity of Old English verse, in contrast to the Old Norse where these types of sound devices are extremely rare. In Old English verse the rhythmical organisation of verse does not coincide with the syntactic organisation, so lines do not make complete syntactic units, but sentences begun in a second half-line tend to continue through following lines, ending in the middle of long lines. The use of sound devices in neighbouring long lines serves to coordinate the syntactically united parts of the sentence and strengthens the caesura marking the beginning of a new sentence. These kinds of sound devices are absent in only one typologically early Old English poem, Widsith, in which each long line usually forms a complete syntactic unit.

In typologically late Christian poems, sound devices involving the first three lifts of neighbouring long lines are used more rarely (in Christ four examples, in Elene six, in Juliana two, in The Fates of the Apostles none). In these poems preference (evinced in more than 70 examples) is given to sound repetitions breaking the long line into two mutually correlated rhythmical segments: ræd peahtende / rice healdan // dugupum wealdon / ac para dom leofað (Elene 449-450).

In typologically later poems such as The Paris Psalter and The Metres of Boethius, end rhymes between long lines (as well as end rhymes in long lines) are used even more frequently. Precise sound repetition of root morphemes, sometimes accompanied by sound coincidence of the suffixal syllables, occurs here more than 80 times, for example: syððan ongledon wesað / gearwe ahyrde // wa me pære wyrde / pæt min wynn alæg (Paris Psalter 119.4-5). For the first time in Old English verse in the lines of these poems, which show a tendency to isosyllabic structure, sound devices arise from the juxtaposition of homonyms, whose sound similarity is underlined by the isomorphism of the metrical units: wene ic forpon / pæt heo wel mæge // pæt swyðre mægen / sawel usser (Paris Psalter 86. 14-15). The use of homonymous sound devices in typologically late poems can be contrasted with the tautological sound repetitions in typologically early ones. Whereas tautological sound devices are characterised by the unity of sound and meaning, in homonymous sound devices the identity of the expression plane underlines the dissimilarity of the semantics, revealing their structural correlation.

The strengthening and refinement of the qualitative structure of the end sound devices are accompanied by quantitative growth. In The Paris Psalter, for example, both types of end-sound devices (those within one long line and those in the neighbouring long lines) gain both preponderance and superiority over other types. In comparison with Beowulf the number of sound repetitions on the end lifts of half-lines increases here by a factor of 14 (104 examples), while the corresponding number in neighbouring long lines increases by more than 13 times (97 examples).

Of the two types of sound repetition the greater functional role in typologically late poems is acquired by the sound devices in the neighbouring long lines (on the fourth lift of the odd long line and on the second lift of the even long line). The horizontal rhythmical row, which was preserved when the first type of end rhyme (on the second and fourth lifts of one long line) was used, disintegrates with the help of sound devices of the second type (on the fourth lift of the odd long line and on the second lift of the even long line) into two independent units, which are correlated by adjacent sound devices. Moreover end rhymes, which are used in two neighbouring long lines and require a pause between them, conflict with the Hakenstil of Old English verse, in which syntactic and metrical division did not coincide, as reflected in sentences starting and ending in the middle of long lines.

The increase in both the quantity and the importance of end rhyme and the weakening of alliteration facilitated the appearance of poems like The Death of Alfred, one of the six poems included into The Anglo-Saxon Chronicle and therefore precisely dated (1036), 
which is already composed neither in alliterative nor in rhyming verse (Ac Godwine hine pa gelette / and hine on hæft sette, // and his geferan he todraf, / and sume mislice ofsloh; // sume hi man wið feo sealde, / sume hreowlice acwealde, // sume hi man bende, / sume hi man blende, // sume hamelode, / sume hættode). Scholars either refused to treat The Death of Alfred as poetry and fully excluded it from their study (Townsend 1996: 143-176), or considered it to be composed in the lower style of alliterative verse (Clark 1971:230), or associated it with primitive forms of rhyming couplets (Oakden 1930: 135), fully breaking from the tradition of alliterative verse (Pearsall 1971:71) and approaching the Middle English system of versification (Friedlander 1979:222).

The Death of Alfred is the first Old English poem (not counting The Rhyming Poem) in which the number of lines with rhyme equals the number of lines with alliteration $(14 \text { out of } 20)^{\text {iv }}$. In contrast to classical verse alliteration in this poem loses its structural function and acquires an ornamental role; this is confirmed not only by the presence of lines without alliteration but also by the use of alliteration on the final lift of the even line (ful wurðlice, / swa he wyrðe wæs 18), which was not allowed by the canons of alliterative verse. In several lines metrical stress falls on one syllable (e.g., Godwine, gelette), and alliteration marks the other (Ac Godwine hine pa gelette / and hine on hæft sette). Alliteration is no longer confined to the semantically most important words of the line, sometimes falling on auxiliary words (wæs, hine).

The accentual pattern of lines in the poem also begins to deviate from the canons of alliterative verse. Lines with three fully stressed syllables are permitted in the poem, which was impossible in alliterative verse (e.g. the line Se apeling lyfode ba gyt 16a, with the metrical scheme containing unusual anacrusis $[\mathrm{X}] \_\mathrm{XX} / \mathrm{XXX} /$, in which the final syllable is apparently stressed and carries the consonance rhyme with the verb 'gehet'). Anacrusis in the poem is used more frequently than in classical verse (initial and final unstressed syllables occur in 25 half-lines out of 40, cf. Ac Godwine hine ba gelette 6a, seo saul is mid Criste 25b); lines become longer (the second and the third lines consist of 16 syllables), the number of unstressed syllables increases (in the second and third lines we find 12 unstressed syllables), which extinguishes alliteration.

The rhythmical organisation of lines in the poem approaches the rhythm of colloquial speech; each half-line almost comprises a short phrase with the natural word-order ( 14 half-lines out of 40 are complete sentences, two contain clauses, the remaining 24 are syntactically independent units). The coincidence between the borders of the syntactical and rhythmical rows breaks from the Hakestil of classical alliterative verse. The role of end rhyme (sealde : acwealde, bende : blende, hamelode : hættode), involving the final lifts in half-lines and requiring a pause between them, becomes indispensible for the newly developing end-stopped rhythm.

Consonantal end rhymes are used in the poem by themselves (scyld $e$ : acweald $e$ 10), and other consonances appear in combination with alliteration (gelyfenne : leofan 8, wurðlice : wyrðe 18), spreading over several long lines (dreorlicre : dæd: gedon : Dene 6-7). Six half-lines of the poem contain full rhymes or consonances or inflectional rhymes: lende: blende: blindne; munecon : wunode : lyfode. In both triads the first pair contains full root morpheme rhyme (lende : blende, munecon : wunode), the second pair adds a repetition of the initial syllables (alliteration: blende : blindne), or final syllables (wunode : lyfode), completing a highly emphatic passage. Alliteration and rhyme both have an expressive function in the poem: they are used in the lines enumerating tortures inflicted on Alfred's companions and their suffering. Alliteration in this poem is used just as consistently as rhyme, but the end rhyme already begins to perform a compositional or organising role in the verse, thus rivalling alliteration in function.

It is possible to conclude that in typologically early Old English poems those sound devices which strengthen alliterative verse prevail. Consonances and full rhymes are born in units of poetic speech, such as compound words, lexical repetitions, repetitions of genetically related words and formulas, and from these spread to the metrical units of verse. The change in distribution of the different types of rhymes and consonances within halflines and long lines can be accounted for by the changes taking place in alliterative verse.

Occupying even half-lines, internal rhymes tend to include the weakest metrical position in the long line, violating the hierarchy of metrical stresses in alliterative verse. Thus this sound device proper (that is unrelated to the units of poetic language) tends to be used in even lines. On the other hand, the weakest position in the long line, the fourth, usually lacks any sound devices except the rhyme appearing in one type of unit of poetic language rhymed formulas. The last stressed syllable of the long line appears to be avoided by other units of poetic language such as alliterative formulas, lexical repetitions and even compound words with rhyming components. 
The importance of the last stressed position in even lines can be accounted for by the greater significance of rhyme for even lines as opposed to odd lines, where two of the stressed syllables were already involved in the alliterative pattern. Thus rhyme introduced by the use of formulas spreads into half-lines and becomes a purely sound device, demotivated from the semantically relevant units of poetic speech, as in the hendingar of skaldic poetry $^{\mathrm{v}}$. It was in the last stressed syllable in the even lines that full rhyme was canonised earliest of all in skaldic poetry. In skaldic verse strengthening of the half-line and its emergence as the main metrical unit of verse resulted in the shattering of phrasal rhythm and destruction of the autonomy of the long line (Smirnitskaya 1994: 335390).

However in England the transformation of alliterative verse occurred not through the development of internal rhyme, as in skaldic verse, but through the development of end rhyme. That is why in typologically late texts, where alliterative verse begins to metamorphose, internal rhymes are used comparatively rarely, but the repetition of sounds usually involves the fourth stressed syllable of the line, which was avoided by alliteration. In typologically late poems, among the various sound devices participating in the phonetic arrangement of verse, end-sound devices, which destabilise the structure of alliterative verse, become more prominent and acquire functional significance. The main role in the destruction of alliterative metre and the transition from the system of versification based on alliteration to the new type of metrical structure belongs to end rhyme. However, although the process of developing and gradually strengthening end-sound devices began in Old English poetry, the poets never (with the exception of The Death of Alfred) violated the main principle of the traditional art of versification: the use of alliteration in its compositional function is obligatory, whereas the additional use of other sound devices remains optional.

Analysis of the sound organisation of alliterative verse appears to establish the most reliable criterion for tracing the evolution of Old English metre and can therefore be used to assess the reliability of other criteria such as changes in phonology, hypermetric lines, placement of the caesura and alliterative canons.

\section{Bibliography}

The Anglo-Saxon Poetic Records: a Collective Edition. (1936-1954). Ed. G. Ph. Krapp, E.van K. Dobbie. Vol. I VI. New York: Columbia Univ. Press, London: Routledge and Kegan.

Amos, A.C. (1980). Linguistic Means of Determining the Dates of Old English Literary Texts. Cambridge, Massachusetts: Medieval Academy of America.

Bliss, A.J. (1967). The Metre of Beowulf. 2nd ed. Oxford: Blackwell.

Bredeshoft, Th. (2009). Authors, Audiences, and Old English Verse. Toronto: University of Toronto Press.

Campbell, A. (1959). Old English Grammar. Oxford: Oxford University Press.

Campbell, A. (1938). The Battle of Brunanburh. London: William Heinemann.

Clark, C. (1971). The Narrative Mode of The Anglo-Saxon Chronicle before the Conquest. In P.Clemoes, K. Hughes (Eds.), England before the Conquest: Studies in Primary Sources presented to Dorothy Whitelock (pp. 215-235). Cambridge: Cambridge University Press.

Friedlander, C.v.D. (1979). Early Middle English Accentual Verse. Modern Philology, 76, 219-30.

Fulk, R.D. (1992). A History of Old English Metre. Philadelphia: University of Pennsylvania Press.

Foster, T.G. (1892). Judith. Studies in Metre, Language and Style, with a View to Determining the Date of the Old English Fragment and the Home of Its Author. Strassburg: M.Neumann.

Goossens, L.A. (1969). Chronology of the Falling together of Late Old English hr and r. In: English Studies. Vol. 50, 74-9.

Gurevich, E.A. (1986). The Formulaic Pair in Eddic Poetry: an Experimental Analysis. In: Structure and Meaning in Old Norse Literature. New Approaches to Textual Analysis and Literary Criticism. Ed. J.Lindow, L.Lönnroth, G.W.Weber. Odense: Odense University Press. P. 32-55.

Gurevich, E.A., Matyushina, I.G. (2000). Poesia skaldov. Moscow: The Russian University for the Humanities Press.

Klaeber, Fr. ed. (1950). Beowulf and the Fight at Finnsburg. Boston: Heath.

Kluge, F. (1884). Zur Geschichte des Reimes im Altgermanischen. Beiträge zur Geschichte der deutschen Sprache und Literatur. Bd. 9, 422-450.

Kuryłowicz, E. (1975). Metrik und Sprachgeschichte. Wrocław: Zakład Narodowy im. Ossolińskich.

Lehmann, W. (1956). The Development of Germanic Verse Form. Austin: University of Texas Press. 
Luick, K. (1964). Historische Grammatik der englischen Sprache. Stuttgart: Bernhard Tauchnitz, Oxford: Blackwell.

Malone, K. (1943). Plurilinear Units in Old English Poetry. In: Review of English Studies. Vol. 19, 201-204.

Malone, K. (1967). The Old English Period (to 1100). In: A Literary History of England. Ed. A.C.Baugh et al. 2 ed. New York: Appleton - Century - Crofts.

Matyushina, I. (1994). On the Development of Rhyme in Old Norse Poetry. In: Nordica Bergensia. Vol. 3, 103138.

Matyushina, I. (2011). Rhymed Formulas in Anglo-Saxon Verse. In: La formule dans la littérature et civilisation de l'Angleterre médiévale. (P. 31-53). Ed. C. Stevanovitch, É. Louviot, Ph. Mahoux-Pauzin, D. Hascoët. Nancy: Presses Universitaires de Nancy.

Meletinsky, E.M. (1986). Commonplaces and other elements of folklore style in Eddic Poetry. In: Structure and Meaning in Old Norse Literature. New Approaches to Textual Analysis and Literary Criticism. Ed. J.Lindow, L.Lönnroth, G.W.Weber. Odense: Odense University Press. P. 15-31.

Oakden, J.P. (1930). The Dialectal and Metrical Survey. Vol.: I Alliterative Poetry in Middle English. Manchester: Manchester University Press.

Pearsall, D.A. (1977). Old English and Middle English Poetry. The Routledge History of English Poetry. London: Routledge \& Kegan Paul.

Pope, J.C. (1966). The Rhythm of Beowulf. New Haven: Yale University Press.

Pope, J.C. (1982). Seven Old English Poems. 2nd edition. New York: W. W. Norton \& Co.

Rearhard, J. A. (1984). Thematic Analysis of the Occurrence of the Hypermetric Lines in Old English Poetry. A thesis for the degree of Master of Arts in English. Reno: University of Nevada.

Sievers, E. (1893). Altgermanische Metrik. Halle (Saale): Max Niemeyer Verlag.

Sievers, E., Brunner K. (1951). Altenglische Grammatik. Halle (Saale): Max Niemeyer Verlag.

Smirnitskaya, O.A. (1994). Stikh i yazyk drevnegermanskoy poesii. Moscow: Moscow University Publishing House. Vol. I-II.

Stanley, E.G. (1975). Verbal Stress in Old English Verse. Anglia. Vol. 93, 307-334

Timmer, B.J. (1951). Expanded Lines in Old English Poetry. Neophilologus. Vol. 35, 226-230.

Timmer, B.J., ed. (1952). Judith. London: Methuen.

Townsend, J. (1996). The Metre of the Chronicle-verse. Studia Neophilologica, 68, 2, 143-176.

Trautmann, M. (1898). Kynewulf, der Bischof und Dichter: Untersuchungen über seine Werke und sein Leben. Bonner Beiträge zur Anglistik. Bonn: P. Hanstein.

\footnotetext{
${ }^{\mathrm{i}}$ Examples from Anglo-Saxon poetry are quoted from The Anglo-Saxon Poetic Records: a Collective Edition. 1936 - 1954.

${ }^{\text {ii }}$ Some scholars think that in The Battle of Maldon only palatal consonants alliterate in these lines (Campbell 1938: 33, Amos 1980:101).

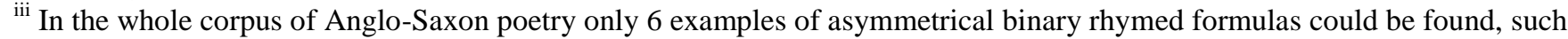
as lac and luftacen, Andreas 1135a, helo and helpend, Par. Psalt 104.15a. All six examples (with one exception: cuð and uncuð, Metr. Boet. 31, 6a) employ alliteration as well as rhyme.

${ }^{\text {iv }}$ Rhyme in The Death of Alfred is used so often that the introduction of several conjectures enabled some scholars to claim fully rhymed verse throughout the whole poem (Holthausen F.1937:157-158).

${ }^{v}$ The main functional factors in the canonisation of rhyme in skaldic verse are: the demotivation of stress, requiring rhyme as a formal marker to complement alliteration, the splitting of the alliterative long line and the appearance of a new poetic unit, the short line, which needs a sound device of its own (internal rhyme), and the formalisation of sound patterns (alliteration and rhyme), establishing phonetic identity irrespective of semantic similarity (Smirnitskaya 1994: 335-390).
} 